\title{
CREATING MODERN DESIGNS FOR NARROW INTERIOR SPACES INSPIRED BY THE ART OF ORIGAMI
}

\author{
Sanjak Ibrahim Mustafa MUHAMMAD, Naglaa Ezzat Ahmed MAHMOUD *
}

Interior Design and Furniture Department, Faculty of Applied Arts, October 6 University, Egypt

\begin{abstract}
When it comes to design our homes, which have a limited space, we are looking for all available means to successfully "furnish" the house, despite its limited space, so it is imperative to reach the smartest solutions for furnishing this house. These solutions would be conducive to getting the most out of small spaces, and it is preferable to use furniture pieces that are convertible from one function to another so that the furniture pieces perform more than one function, while taking a small space in the house. The multi-use furniture is the result of effective and innovative solutions in the field of interior design to the problem of small living space in light of the population growth and the financial crisis facing the world and the tendency of countries to horizontal expansion which is the acquisition of pieces of furniture that can be transformed from one shape to another or from one job to another in line with the modern style using the art of origami in order to achieve several objectives, including solving the problem of small spaces and making good use of them in addition to adding an aesthetic touch to the interior space, and this is done using the art of origami. Origami is an ancient Japanese art that means forming paper to make three-dimensional models using techniques of folding and carving and combining these techniques with various paper shapes to create composite designs. From the standpoint of emphasizing the role of the interior design in finding solutions for limited spaces, the idea of research came to conclude ideas for multi-use and convertible designs that serve narrow interior spaces using the art of origami.

Keywords

Origami, Interior Design, Multiple Use Furniture, Art, Narrow Interior Spaces.
\end{abstract}

\section{Introduction}

Achieving jobs and providing pleasure in residential spaces with a small and limited area require more innovation from the designer to reach smart solutions that enable the maximum benefit from small spaces, and the research presents a proposal that enables the designer to use the art of origami with its simple materials and techniques in creating interior designs and multi-purpose furniture and uses to solve the problem of small space for residential spaces.

\section{Research Problem}

The research problem is summarized in the traditional and the shortcomings in the interior design and the design of the Egyptian furniture, as it does not fit with the small spaces of the residential interior spaces in terms of function and does not fit with the changes of the times in terms of form.

\section{Research Objectives}

1. Activate the role of modern trends in interior design and convertible furniture to achieve all the required functions in small spaces using the art of origami.

\footnotetext{
*Corresponding author: arts@o6u.edu.eg
} 
2. Shed light on the art of origami in how it can be used to solve interior design and furniture problems.

\section{Research Importance}

1. Drawing a strategy to activate the role of origami art to serve interior design and furniture.

2. Introducing the most important artistic features that express the art of origami in designs.

3. Finding out what the art of origami is and what new features added to it.

\section{Research Methodology}

* The research follows the descriptive and analytical method.

\section{Results}

1. The combination of the art of origami and modern technologies and materials leads to smart, innovative design solutions suitable for the requirements of the times.

2. Versatile furniture with its flexible and transforming design saves effort, time and costs, and helps to solve design problems caused by space constraints.

3. Achieving the principle of multiple uses, whether in interior design or furniture, using origami art combined with modern materials and advanced technology providing the best design solutions that fit the limited space of the Egyptian houses.

\section{Recommendations}

1. The research recommends raising awareness and urging bodies, institutions and factories producing interior design and furniture by using origami art and combining it with modern materials to develop the design product in order to fit with the requirements of the times and the space constraints for residential spaces.

2. The research recommends urging more scientific research on multi-use furniture and how it relates to modern trends such as origami art to make the most of the smart and different solutions provided by this art.

\section{References}

1. Ibrahim, Ashraf Hussein - Qasim, Umaima Ibrahim - Qasim, and Reham Muhammad: "The Influence of the Trend of Modern Organic Theory on Origami Thought" Published Research - Journal of Architecture and Arts - Issue 11 - Part 1. 
2. Bukhari, Firas: "Flexibility in Architectural Design" - Master Thesis - Faculty of Architecture - Damascus University - Syria - December 2009.

3. Rahma, Ahmed Mohamed Ahmed: "Employing the Art of Paper Folding in the Innovation and Creation of Models for the Design of Industrial Products (As Applied to Lighting Units) - Published Research - Journal of Human Sciences - Fifth Issue 2015.

4. Rashid, Badriya Bint Mohsen: "Using Origami as an Innovative Introduction for Contemporary Metalwork Work - Published Research - Arab Journal of Social Sciences Scientific Institution and Human Resources Development - 2017.

5. Bayram,Z., “İşlevsellik ve Esneklik Bağlamında Konut İç Mekân Tasarımında Mobilya Kullanımı', Yüksek Lisans Tezi, Maltepe Üniversitesi, Sosyal Bilimler Enstitüsü, İstanbul, 2011.

6. Burdurlu, E., Baykan İ. “'Dar Hacimli Konutlar İçin Mobilya Tasarımı', Journal of Qafqaz, 215 (224), 2001.

7. Friedman ‘A ‘(1993) "Decision- Making Process for Choice of Flexible Internal Partition Options in Multi-Unit Housing Using Decision Theory Techniques" in Design and Decision Support Systems in Architecture ,Kluwer Academic Publishers Dordrecht , Netherlands

8. Mark Schenk," Origami in Engineering and Architecture", Advanced Structure Group, University of Cambridge, 2012.

9. RobertJ. Lang, "The Complete Book of Origami (Step-by-Step Instructions in Over 1000 Diagrams)", Dover Publictions, New York, 1988.

10. Özer ÖZÇELIKK1*, Timur KAPROL, CONCEPTS THAT SHAPED THE DESIGN OF TRANSFORMABLE FURNITURE, Faculty of Architecture, University of Trakya, Edirne/TURKEY

11. Özturan,Ö., “'Teknolojik Gelişmelerin İç Mekân Biçimlenişine Etkisi’’, Tasarımda Genç Bakışlar Sempozyumu, İstanbul Ticaret Üniversitesi, , İstanbul, 2010.

12. www.arabicorigami.blogspot.com/search/lable/

13. https://www.archdaily.com/28649/bengt-sjostrom-starlight-theatre-studio-gangarchitects/

14. http://www.busyboo.com

15. www.ceneonline.com

16. https://www.designswan.com/archives/furniture-transformer-boxetti collection.html 17. http://www.dwellbeautiful.com 
18. http://gizmodo.com/5-smart-building-skins-that-breathe-farm-energy-and-g1254091559

19. 1https://www.homedit.com/creative-and-modular-furniture

20. http://inhabitat.com/ottong\% E2\%80\%99s-robotic-wallbot-wallsautomatically moveto-adapt-toyoulifestyle/ book-3-indd/

21. www.nygeekcast.com

22. http://shinple.com

23. www.or.wikipedia.org/wiki/ أوريجامي

24. www.w-dd.net/ design_ask/wp-content

25. http://www.w-dd.net/design_ask/wp-content/uploads/2016/11/Screen-Shot-2016

26. https://mobykan.com/mag/ar-eg

27. http://www.wired.com/2014/09/a-new-concept-for-shape-shifting-architecture-thatresponds-to-heat/\#slide-1

28. http://rvtr.com/research/resonantchamber/

29. http://inventorcentre.net/storage/1515-futuristic-interior-boxetti-collection-rolandslandsbergs.html

30. https://www.godownsize.com/furniture-for-small-spaces/

31. https://honghuali.github.io/projects/foldem/foldem.pdf

Received: February 18, 2018

Accepted: April 5, 2018 